\title{
REACTIVITY OF NUCLEOPHILES AND a-EFFECT IN SUBSTITUTION PROCESSES AT ELECTRON - DEFICIENCY CENTERS (Part 2)
}

\section{A. F. Popov', I. V. Kapitanov ${ }^{1,3}$, A. A. Serdyuk ${ }^{1,3}$, A. E. Shumeiko ${ }^{1,2^{\star}}$}

${ }^{1}$ Institute of Physical Organic Chemistry and Coal Chemistry, L. M. Litvinenko NAS of Ukraine; Kharkiv highway 50, Kyiv 02160, Ukraine.

${ }^{2}$ Institute of Organic Chemistry, NAS of Ukraine; st. Murmanskaya 5, Kyiv 02660, Ukraine

${ }^{3}$ Center for Excellence in Green Chemistry, European Research Area. Department of Chemistry and Biotechnology, Faculty of Science, Tallinn University of Technology, Academia 15, 12618 Tallinn, Estonia

*E-mail: ashumeiko@ukr.net

The review analyzes issues related to the reactivity of nucleophiles and the manifestation of the a-effect in substitution processes at electron-deficient centers. The fundamental aspects of this phenomenon, as well as the possibilities and prospects of using a-nucleophiles in systems for the highly efficient degradation of substrates - ecotoxicants of various natures, are discussed.

Key words: functionalized surfactants, $a$-nucleophiles, micellar systems, hydroxylamine, oximes, amidoximes, hydroxamic acids, peroxides.

\section{Use of micellar systems to increase the ef- ficiency of reactions of ecotoxicants degradation by supernucleophilic reagents}

It is rather difficult to create a compound that, in an aqueous solution, would be superior to the hydroxylamine anion in its nucleophilic reactivity. Therefore, the way to increase the efficiency of systems for the splitting of ecotoxicants should be not so much trough the structural modification of the splitting agent, but rather trough the use of alternative methods of influencing the reaction rate, for example, by changing the properties of the medium, in which it occurs $[3,4,7,8]$.
Microorganized media (micellar solutions, microemulsions, ionic liquids, concentrated aqueous solutions of quaternary ammonium salts, etc. $[3,4,7,8,94-100])$ have been in the center of attention of researchers for quite a long time. They are widely used to solve several applied and fundamental problems, such as modeling biological objects [38, 96, 100], implementing various technological processes $[96,98]$, preparing samples for chemical analysis [97], etc. Carrying out chemical reactions in microorganized systems is of great practical interest since it opens up new possibilities for influencing the rates and products of reactions [94-100]. 
The undoubted advantage of micellar systems, in comparison with other organized microheterogeneous media, lies in the fact that a radical change in the properties of the medium is achieved by introducing sufficiently small amounts of micelle-forming substances (in quantities higher than the critical concentration of micelle formation, which is about $\left.10^{-6}-10^{-2} \mathrm{~mol} \cdot \mathrm{l}^{-1}\right)[96,97]$. In this case, the main component of such systems in most cases is water, which makes them extremely attractive for practical application from the standpoint of "green" chemistry [101].

Carrying out the process of cleavage of organophosphorus ecotoxicants in the presence of surfactant micelles allows solving the problem of solubilization of substrates (most OPCs are poorly soluble in water) [75-78], as well as increasing the observed reaction rate due to the implementation of the micellar catalysis effects $[3,4,7,8,96-99]$.

\subsection{Features of the course of chemical reac- tions in the presence of surfactant micelles.}

The presence of surfactant micelles can significantly affect the rates of chemical reactions due to the implementation of the micellar catalysis effects [96-99]. The essence of it is change in the local concentrations and reactiv- ity of substrates and reagents when the reaction is transferred to the micellar pseudophase, as well as the shift of protolytic equilibria in such solution. The nature of the effect (catalysis or inhibition) depends on surfactant type (cationic, anionic, nonionic) the reagent charge. In most cases, cationic detergents accelerate reactions involving negatively charged particles, and anionic - positively charged ones. Nonionic surfactants, in the case of using charged or sufficiently polar reagents, practically do not change the reaction rate $[98,99]$.

To describe the kinetics of the processes occurring in the presence of surfactant micelles two main models are usually used - pseudophase distribution and ion-exchange $[98,113-$ 120].

The pseudophase distribution model proposed by Berezin et al. [98, 113-115], based on the fact that surfactant solutions above the CMC consist of two phases (aqueous phase and micellar pseudophase), between which there is an equilibrium distribution of reagents occurts that is not disturbed by the proceeding reaction. It is assumed that the reagents do not affect properties of micelles and do not change the CMC.

In general, the kinetic scheme of the bimolecular reaction proceeding in such a system can be represented as follows (Fig. 14).

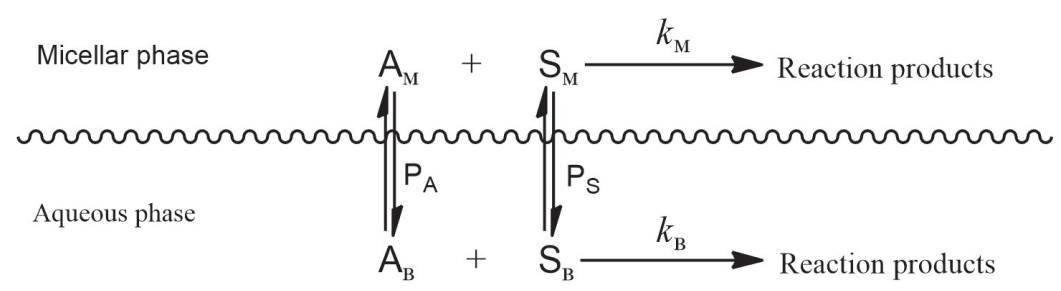

Fig. 14. Scheme of a bimolecular reaction proceeding in the presence of surfactant micelles: where $\mathrm{P}_{\mathrm{S}}=[\mathrm{S}]_{\mathrm{m}} /[\mathrm{S}]_{\mathrm{w}}$ and $\mathrm{P}_{\mathrm{A}}=[\mathrm{A}]_{\mathrm{m}} /[\mathrm{A}]_{\mathrm{w}}$ are the distribution coefficients of the substrate $(\mathrm{S})$ and the reagent $(\mathrm{A})$; $k_{\mathrm{m}}$ и $k_{\mathrm{w}}, \cdot \mathrm{mol}^{-1} \cdot \mathrm{s}^{-1}$ are the reaction rate constants in micellar pseudophase $(\mathrm{m})$ and aqueous phase $(\mathrm{w})$ respectively 
The mathematical expression for the observed reaction rate constant $k_{\mathrm{o}}, \mathrm{s}^{-1}$, in this case will have the form:

$$
k_{o}=\frac{k_{\mathrm{m}} P_{\mathrm{A}} P_{\mathrm{S}} \mathrm{CV}_{\mathrm{m}}+k_{\mathrm{w}}\left(1-\mathrm{CV}_{\mathrm{m}}\right)}{\left(1+\left(P_{\mathrm{A}}-1\right) \mathrm{CV}_{\mathrm{m}}\right)\left(1+\left(P_{\mathrm{S}}-1\right) \mathrm{CV}_{\mathrm{m}}\right)}
$$

In equation (7), $\mathrm{C}$, mol. $\mathrm{l}^{-1}$, is the total surfactant concentration minus the $\mathrm{CMC} ; \mathrm{V}_{\mathrm{m}}$, $1 \cdot \mathrm{mol}^{-1}$, is the molar volume of the surfactant.

Taking into account that, in the case of dilute surfactant solutions, the volume fraction of the micellar pseudophase is small $(\mathrm{CV}<<1)$, and we assume that the binding of reagents occurs efficiently $\left(P_{\mathrm{S}}, P_{\mathrm{A}>}>1\right)$, expression (7) can be simplified:

$$
k_{o}=\frac{\left(k_{\mathrm{m}} / \mathrm{V}_{\mathrm{m}}\right) K_{\mathrm{A}} K_{\mathrm{S}} \mathrm{C}+k_{\mathrm{w}}}{\left(1+K_{\mathrm{A}} \mathrm{C}\right)\left(1+K_{\mathrm{S}} \mathrm{C}\right)} .
$$

where $K_{\mathrm{S}}=\left(P_{\mathrm{S}}-1\right) \mathrm{V}_{\mathrm{m}}$ and $K_{\mathrm{A}}=\left(P_{\mathrm{A}}-1\right) \mathrm{V}_{\mathrm{m}}$ are the binding constants of the reagent and substrate with the micellar pseudophase.

The pseudophase distribution model describes most of the processes occurring in the presence of surfactant micelles quite well [98, 114]. However, when studying reactions involving high concentrations of small hydrophilic ions, such as, for example, hydroxide ion, its use does not give an adequate picture, since in this case the processes of ion exchange in the Stern layer begin to play a decisive role $[116,117]$. To describe the kinetics of such reactions, it is advisable to use the ion-exchange model, which considers this feature and allows calculating the ion exchange constant characterizing the saturation of the Stern layer with reactive counterions. This model is described in detail in papers [116-120]. Unfortunately, the direct determination of the ion exchange constants is a rather complicated experimental problem $[116,117]$, which in many cases significantly limits the possibilities of its application.

\subsection{Reactions of ecotoxicants cleavage by nucleophilic reagents in micellar systems}

The use of cationic surfactants solutions as a medium for carrying out the degradation of ecotoxicants by nucleophilic reagents makes it possible to effectively solubilize OPC, most of which, in the absence of detergents, are poorly soluble in water, as well as to ensure the wetting of hydrophobic and highly developed surfaces $[4,8,77,96]$. In this case, the realization of the effects of micellar catalysis leads to an additional increase in the rate of the process of electron-deficient substrates cleavage by nucleophilic reagents (hydroxide ion, oxymate, hydroxamate ions, etc.) by a factor of $10-10^{3}$ [85-88; 113-131]. In works [85-88; 113-131], it was repeatedly shown that at the background of minor changes in nucleophilic reactivity during the transfer of the reaction from water to the micellar pseudophase, an increase in the reaction rate is provided due to the concentration of reagents in surfactant micelles. As a rule, in reactions involving organic nucleophiles, the concentration effect is more pronounced than for inorganic ones. Thus, for example, in the reactions of alkaline hydrolysis of the substrates indicated below, it is, on average, one order of magnitude, and for reactions with 3-bromobenzaldoxime - from 60 (p-nitrophenyl acetate) to $2 \cdot 10^{3}$ (p-nitrophenyl heptanoate) times [115].

A typical profile of a bimolecular reaction proceeding in the presence of cationic surfactant micelles is shown in Fig. 15. With an increase in the concentration of the de- 
tergent, the reaction rate increases, reaches a maximum, and then decreases. This type of dependence is because with an increase in the surfactant concentration, the number of reagents bound by the micellar pseudophase increases. After the entire substrate and the agent that decomposes it are bound by micelles (maximum point), a further increase in the surfactant concentration will lead to a decrease in the reaction rate due to an increase in the volume of the micellar pseudophase and, as a consequence, a decrease in the local concentrations of reagents [131].

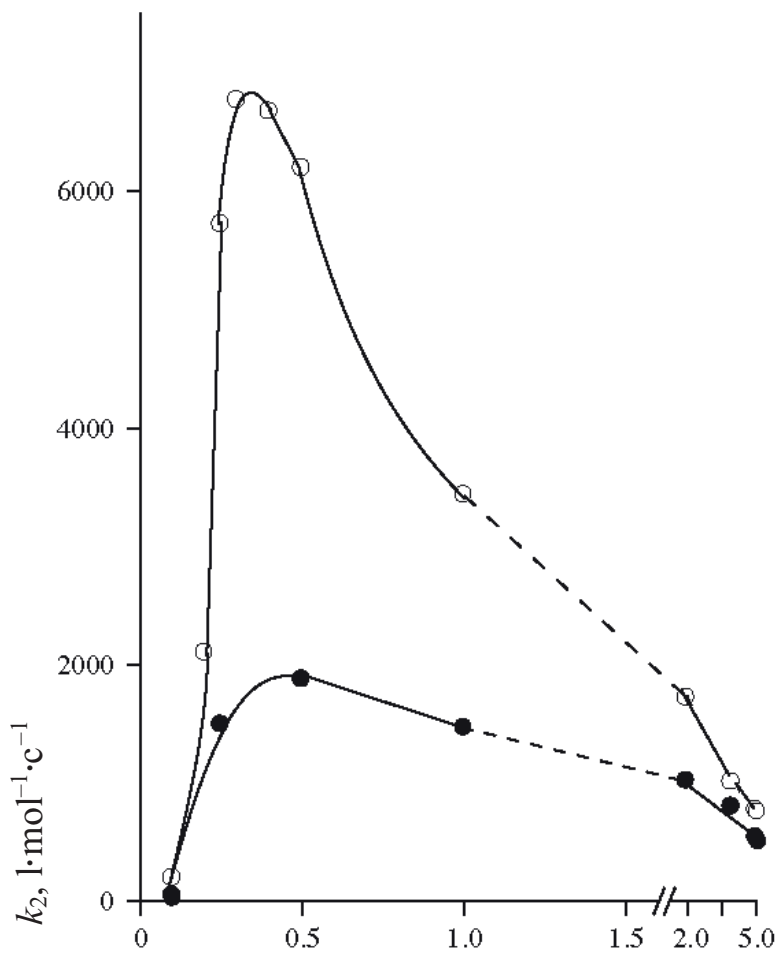

$[\mathrm{CTAB}] \cdot 10^{3}, \mathrm{~mol} \cdot \mathrm{l}^{-1}$

Fig. 15. Micellar effects of cetyltrimethylammonium bromide (CTAB) for reactions of interaction of 4-nitrophenyl diphenylphosphate with 4-nitrobenzaldoxymate $(\bullet)$ and 2-quinolin aldoxymate (O) ions [131].

\section{Functional surfactants containing an $\alpha-n u-$ cleophilic fragment are highly effective reagents in the transfer of acyl groups.}

Despite the fact that the presence of cationic surfactant micelles makes possible to significantly increase the rates of the reactions of model substrates cleavage by nucleophilic reagents, the efficiency of such systems is still insufficient $[4,8]$. First of all, this is due to the fact that the binding of nucleophiles by the micellar pseudophase is often characterized by rather small distribution coefficients [85-88, 113-131]. One of the most promising ways to increase the efficiency of nucleophilic reagents binding to micelles is to create functional detergents - surfactants, containing in their structure reactive fragments. When this approach is implemented, the concentration of nucleophilic groups on the micelle surface will always be equal to the surfactant concentration $[3,4]$. Since micellar systems were repeatedly used as models of enzymes [38, 96, 100], initially groups and fragments of amino acids were introduced into the structure of surfactant molecules, which are present in the active center of enzymes and are responsible for the catalysis. During the development of this direction, a large number of functional surfactants of the most varied structure were synthesized and studied, containing as a reactive fragment an imidazole nucleus (XXX -XXXVI [132-140]), hydroxyl (XXXVIII -XLII [132, 136, 137, 139, 141-144]), thiol (XLIII-XLVI $[138,140,145,146])$, amino group (XLVIIXLVIII [140, 145]), etc. However, an increase in the rate of model substrates splitting with these functional detergents, in comparison with alkaline hydrolysis in the presence of non-functional surfactants, was small (it was 
<smiles>CCCn1ccnc1</smiles>

XXX<smiles>C[N+](C)(Br)Cc1cnc[nH]1</smiles>

XXXI<smiles>CCC(=O)NCCc1c[nH]cn1</smiles>

XXXII

XXXIII

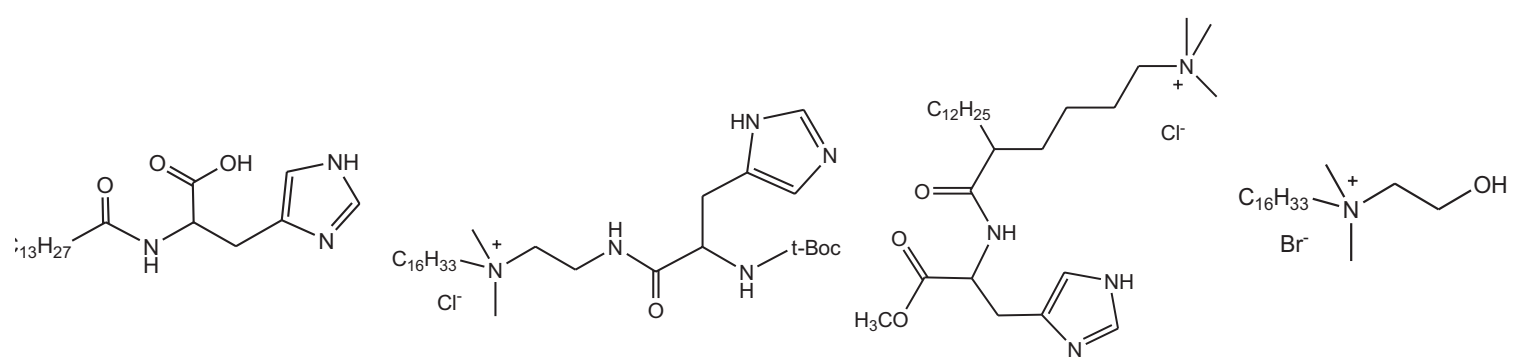<smiles>[X][W]([W])=[W]</smiles>

XXXVIII<smiles>CC(C(O)c1ccccc1)[N+](C)(C)Br</smiles>

XXXIX<smiles>CCCCCCCCCCCCCC(=O)NC(CO)C(=O)O</smiles>

XLII<smiles>C[N+](C)(Cl)CCS</smiles>

XLIII<smiles>C[N+](C)(Cl)CCNC(=O)C(N)CS</smiles>

XLVI<smiles>C[N+](C)(Cl)CC[N+](C)(C)CCN</smiles>

XLVII<smiles></smiles>

XL<smiles>CCCCCCCCCCCCC(=O)NC(CS)C(=O)O</smiles>

XLIV<smiles>CN(C)CC(O)O</smiles>

XLI

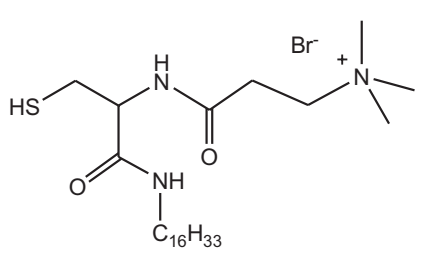

XLV<smiles>CC(N)C(=O)NCC[N+](C)(C)Cl</smiles>

XLVIII

1.5-6 times) and significantly lower than the rates of enzymatic reactions [132-146]. These data clearly demonstrated that the introduction of fragments of "normal" nucleophiles into the structure of surfactants does not give the expected results.

A much more productive direction in the design of the structure of highly reactive functional surfactants was the use of an a-nucleo- phile fragment as a functional group $[3,4,7$, $8,10,11]$. Such detergents supports providing not only effective solubilization of sufficiently hydrophobic and, as a result, poorly water-soluble substrates (such as most organophosphorus pesticides and neuroparalytic CWA) [7578], but also their abnormally fast degradation due to a-effect of a functional fragment $[3,4$, $7,8,10,11]$. At the moment, the main types 
of functional surfactants containing a supernucleophilic fragment are detergents based on hydroxylamine derivatives [147-172], as well as detergents, which include peroxy [173] and iodosocarboxylate groups $[11,174-146]$.

\subsection{Reactivity of functional surfactants based on hydroxylamine derivatives.}

Between functional a-nucleophilic fragments to be introduced into the surfactant structure, the greatest and quite natural interest was aroused by hydroxylamine. It is the ancestor of compounds of three different classes (oximes, amidoximes, hydroxamic acids) that are stable, easy to obtain and allow modifying the basic structure within a wide range [10], which is undoubtedly important in the search for surfactants with an optimal combination of properties. At the same time, effective work in this direction will be difficult without developing a unified scientifically grounded approach to modifying the structure of functional surfactants. Therefore, the main efforts should be directed at establishing the patterns of changes in the nucleophilicity of functional detergents and developing a method that allows its prediction [4].

9.2 Reactivity of functional detergents containing a hydroxamate moiety.

A significant advantage of hydroxamic acids as cleaving agents over other derivatives of hydroxylamine is that their functional group transforms into a highly reactive anionic form (hydroxamate anion) even at rather low $\mathrm{pH}$ values. This allows carrying out the reactions of decomposition of acyl-containing substrates under "mild" conditions - when the acidity of the medium is close to neutral. In this regard, the creation of surfactants containing a hydroxamate fragment seems to be very attractive and promising [4]. The main directions for modifying the structure of these surfactants included:

- changing the properties of the hydrophobic fragment and the place of its introduction;

- introduction of catalytically active centers;

- introduction of positively charged centers.

By varying the length of the alkyl chain in hydroxamic acids XLIX (Alk $=\mathrm{C}_{5} \mathrm{H}_{11}, \mathrm{C}_{7} \mathrm{H}_{15}$, $\mathrm{C}_{9} \mathrm{H}_{19}, \mathrm{C}_{11} \mathrm{H}_{23}, \mathrm{C}_{15} \mathrm{H}_{31}$ ), and studying their reactivity in the processes of cleavage of a series of 3-nitro-4-acyloxybenzoic acids, it was shown [147] that the transition from non-micelle-forming $\left(\mathrm{Alk}=\mathrm{C}_{5} \mathrm{H}_{11}, \mathrm{C}_{7} \mathrm{H}_{15}\right)$ to micelle-forming $\left(\mathrm{Alk}=\mathrm{C}_{11} \mathrm{H}_{23}, \mathrm{C}_{15} \mathrm{H}_{31}\right)$ compounds leads to an increase in the observed reaction rate constants, while an increase in the hydrophobicity of the substrate reduces the rate of the process.

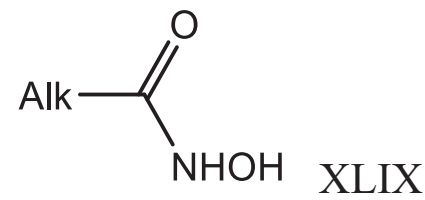

Results similar to those given above (cleavage of 3-nitro-4-acyloxybenzoic acids) were obtained for the destruction of diphenyl phosphate (DPP) $[148 ; 149]$. In this case, micelle-forming hydroxamic acid $\left(\mathrm{Alk}=n-\left(\mathrm{C}_{9} \mathrm{H}_{19}\right) \mathrm{C}_{6} \mathrm{H}_{4}-\mathrm{O}-\right.$ $\left.\left(\mathrm{C}_{2} \mathrm{H}_{4}-\mathrm{O}\right)_{8} \mathrm{CH}_{2}-\right)$ provided an increase in the reaction rate by about 3 times compared to non-micelle-forming $\left(\mathrm{Alk}=\mathrm{C}_{7} \mathrm{H}_{15}\right)$. The introduction of a chlorine atom into the 2-position of hydroxamic acid led to the fact that even for non-micelle-forming compounds $\left(\mathrm{Alk}=\mathrm{C}_{2} \mathrm{H}_{5}\right.$ and $\mathrm{C}_{7} \mathrm{H}_{15}$ ), the rates of DPP cleavage became 
comparable to the rates of cleavage in the presence of micelle-forming surfactant [148, 149]. Replacement of an inert phenyl fragment in hydroxamic acid by an imidazole nucleus leads to an approximately twofold increase in the rate of NPA cleavage [155]. The observed effect is explained by the implementation of intramolecular catalysis of the process of the hydroxamate ion deacylation with an imidazole fragment. The $-\mathrm{CH}_{2}-\mathrm{CH}_{2}$ - bridge between the carbonyl group and the imidazole nucleus reduces the rate of NPA cleavage [155].

The introduction of tetraalkylammonium [148; 149], imidazolium [151, 157-160] or pyridinium [151] positively charged center in hydroxamic acid leads to an increase in its solubility in water [151, 148, 158], and undoubtedly, reduces the constants of acid ionization of the hydroxamate fragment. An increase in the distance between a functional group and a charged center neutralizes influence of the latter [156]. Replacing methyl groups with reactive acethydroxamate fragments not only does not lead to an increase in the observed rate of DPP cleavage, but even decreases it by about a factor of 2 [148, 149].

Under the same experimental conditions, the observed rate constant of the cleavage reaction of NPA by a 2-methylimidazolium functional detergent practically does not differ from that for an unsubstituted imidazolium surfactant containing a pyridinium nucleus [151]. This indicates the absence of a marked influence of the heterocyclic nucleus nature on the reactivity of the hydroxamate fragment.

\subsection{Reactivity of functional detergents con- taining an oximate fragment.}

Compared with other directions of modification, the introduction of an oximate frag- ment into a surfactant molecule has several advantages: firstly, it allows obtaining a large number of compounds with basicity varying over wide ranges $[4,10,158]$, and secondly, surfactants functionalized with an oximate fragment are superior in solubility in water to the derivatives of hydroxamic acids and amidoximes [158]. It should also be noted that additional interest in this area is caused by the fact that it was on the basis of oximes that the most effective antidotes for OPC poisoning (pralidoxime (PAM), isonitrosine, dipiroxime, etc.) were created [77-79], the intensive study of analogs of which continues at the present time [53-61, 92, 93].

The studies carried out cover compounds with a rather diverse structure $[148,149,154$, 157-172], and in papers [148, 149, 161-167] much attention was paid to the study of the reactivity of surfactants, the head group of which is structurally similar to AChE pyridinium reactivators (2-PAM, 4-PAM, etc. [77-79]).

The modification of detergents containing an oximate fragment was carried out in the following directions:

- varying the counterion structure;

- varying the length of the alkyl chain;

- varying the nature of the head group.

Influence of the anion nature. Varying the structure of the anion $\left(\mathrm{Cl}^{-}, \mathrm{Br}^{-}, \mathrm{I}^{-}, \mathrm{MsO}^{-}\right.$, $\left.\mathrm{TsO}^{-}\right)$, carried out for surfactants of different structures $[162,163,170]$, made it possible to demonstrate that their reactivity is practically independent of the nature of counterion.

Varying the length of the alkyl chain. The transition from non-micelle-forming compounds (Alk $\leq \mathrm{C}_{7} \mathrm{H}_{15}$ ) to micelle-forming ones (Alk $\geq \mathrm{C}_{8} \mathrm{H}_{17}$ ) is accompanied by a decrease in the half-transformation time of model substrates into reaction products $[162,163]$, which 
is explained by the realization of the micellar catalysis. Information on the nature of the effect of an increase in the length of alkyl chain on reactivity of micelle-forming substances (with Alk $\geq \mathrm{C}_{8} \mathrm{H}_{17}$ ) is very contradictory. The data are given, from which it follows that with an increase in the length of the alkyl chain, for some cases the nucleophilicity of the functional group increases, while in others the same dependence has the opposite character [148, $162,167]$. The differences in the data obtained can be caused by the fact that with an increase in the length of the alkyl chain, the solubility of the surfactant in water decreases and this leads to complete dissolution of detergent with Alk $=\mathrm{C}_{8} \mathrm{H}_{17}$ [148] at a concentration of $6.0 \cdot 10^{-2} \mathrm{~mol} \mathrm{l}^{-1}$, and partial dissolution of those with Alk $=\mathrm{C}_{12} \mathrm{H}_{25}$ and $\mathrm{C}_{16} \mathrm{H}_{33}$ [148]. A decrease in the amount of a dissolved substance leads to the observed effect of a decrease in the rate of DPP cleavage with an increase in the length of the alkyl chain.

Varying the nature of the head group. The literature [148, 149, 154, 157-172] describes functional detergents containing imidazolium, pyridinium, tetraalkylammonium fragments and an oximate group in the head part of the molecule. The study of their reactivity in the processes of model substrates (NPA, DPP, NPDPP, NPDEP, NPDEP, NPDETP, NPTS, NPB) cleavage showed that they are effective acceptors of acyl groups. Unfortunately, it is rather difficult to carry out a full-fledged comparative analysis based on the available literature data $[148,149,154,157-172]$. This is because the authors use substrates of different reactivity and hydrophobicity, and reaction conditions are significally different (surfactant concentration, degree of ionization of a functional fragment, degree of substrate binding, temper- ature, additives of co-detergents, organic solvents, etc.).

\subsection{Reactivity of functional detergents con- taining amidoximate fragment.}

Functional surfactants based on pyridine [161] and imidazole [157-160], containing amidoximate group as a reactive fragment, are close to functional detergents containing oximate ion in terms of the cleavage efficiency of model acyl-containing substrates. However, since amidoximate group has higher basicity, the cleavage reactions have to be carried out in strongly alkaline media, which is less preferable from a practical point of view [4]. Their rather low solubility in water should also be noted, which creates additional experimental difficulties. Even when using additives of organic solvents (ethyl alcohol, acetonitrile) and co-detergents (CTAB), it is extremely difficult to obtain stable solutions of these substances with a concentration sufficient for effective binding of model substrates [157-161].

\subsection{Reactivity of functional surfactants con- taining a peroxy group.}

Hydroperoxide anion is one of the most effective $\alpha$-nucleophiles in substitution reactions at unsaturated electron-deficient centers [4]. Along with that, only one work [173] is devoted to its introduction into the detergent molecule and the study of the properties of the obtained functional surfactants.

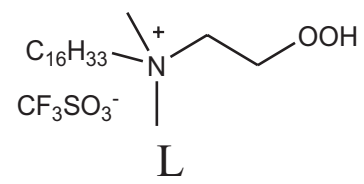


Detergent L, described in [173], was isolated in the form of a mixture with functional surfactant XXXVII, which served as a starting material for the synthesis of $\mathrm{L}$ (the content of the target product L was 60-70\%). When studying the kinetics of NPA cleavage by a XXXVII / L mixture, cetyltrimethylammonium chloride (CTAC) additives were used as a co-detergent (molar ratio of the components of co-micelles L:XXXVII:CTAC = 6:5:4). The observed rate constant of the NPA splitting in<smiles>[R6]c1ccc2c(c1)C(=O)OI2O</smiles>

$$
\begin{aligned}
\mathrm{R}: & \mathrm{C}_{8} \mathrm{H}_{17} \\
& \mathrm{C}_{16} \mathrm{H}_{33}\left(\mathrm{CH}_{3}\right)_{2}-\mathrm{NCH}_{2} \mathrm{CH}_{2} \\
& \mathrm{CH}_{2}\left(\mathrm{CH}_{3}\right)_{2} \mathrm{NCH}_{2} \mathrm{CH}_{2} \\
& \mathrm{I} \\
& \mathrm{CHOOCC} \\
& \mathrm{I} \mathrm{CH}_{15} \mathrm{H}_{31} \\
& \mathrm{CH}_{2} \mathrm{OOCC}_{15} \mathrm{H}_{31}
\end{aligned}
$$

LI the presence of the L / XXXVII / CTAC co-micelles was $0.4 \mathrm{~s}^{-1}(1.42 / 1.30 / \mathrm{CTAC}=0.045 \mathrm{M}$, $\mathrm{pH}=8$ ), which is $\sim 500$ times higher than the observed rate constant for the NPA splitting by arylate ion, which has the same basicity, but in the absence of surfactants.

Another rather attractive direction in the design of systems for the degradation of organophosphorus ecotoxicants is the creation and study of surfactants containing an iodosocarboxylate group [11, 174-176].

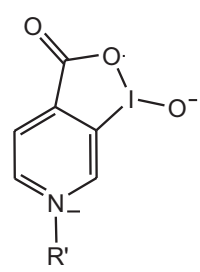

$$
\begin{aligned}
\mathrm{R}^{\prime}: & \mathrm{C}_{8} \mathrm{H}_{17} \\
& \mathrm{C}_{12} \mathrm{H}_{25} \\
& \mathrm{C}_{16} \mathrm{H}_{33}
\end{aligned}
$$

An undoubted advantage of these compounds is that their functional group can be converted into an ionized form at $\mathrm{pH}$ values close to neutral (see table).

Thus, compound LI (b), being one of the most effective nucleophilic reagents of this type, in co-micelles with CTAC, provides extremely high rate of NPDPP cleavage in a weakly alkaline medium $(\mathrm{pH}=8.0)$ [174], and LII (c) allows carrying out decomposition reactions of organophosphorus substrates already at $\mathrm{pH} \geq 6.0[176]$.

Table

Reactivity of functional surfactants containing iodosocarboxylate group in the process of NPDPP cleavage; $\mathrm{pH} \mathrm{8.0,}[\mathrm{PD}]=1.0 \cdot 10^{-4} \mathrm{~mol} \cdot \mathrm{l}^{-1}, 25^{0} \mathrm{C}$.

\begin{tabular}{|l|l|l|l|l|l|l|}
\hline № & Compound & $\mathrm{pK}_{\mathrm{a}}$ & {$[\mathrm{CTAC}], \mathrm{mol}^{-1} \mathrm{I}^{-1}$} & $k_{\mathrm{o}} \mathrm{s}^{-1}$ & $\tau_{1 / 2}, \mathrm{~s}$ & Ref. \\
\hline 1 & LI (a) & 7.20 & $2.0 \cdot 10^{-4}$ & 1.04 & 0.7 & {$[174]$} \\
2 & LI (6) & 6.45 & $2.0 \cdot 10^{-4}$ & 1.14 & 0.6 & {$[174]$} \\
3 & LI (в) & 7.20 & $2.0 \cdot 10^{-4}$ & 0.014 & 50 & {$[175]$} \\
4 & LII (a) & $<5.0$ & $1.0 \cdot 10^{-4}$ & 0.0038 & 182 & {$[176]$} \\
5 & LII (6) & $<5.0$ & $1.0 \cdot 10^{-4}$ & 0.071 & 10 & {$[176]$} \\
6 & LII (в) & 4.85 & $1.0 \cdot 10^{-4}$ & 0.18 & 4 & {$[176]$} \\
\hline Remark. ${ }^{*}$ CTAB was used as co-detergent. \\
\hline
\end{tabular}


The disadvantage of such functional detergents containing iodosocarboxylate group is low solubility in water, which significantly narrows the possibilities of their use $[4,11]$.

CONCLUSIONS. Thus, the presented materials show the following:

1) The phenomenon of the $a$-effect plays an important role in understanding the nature of the nucleophilic reactivity and the mechanisms of nucleophilic reactions involving both "ordinary" organic and inorganic nucleophiles and $\alpha$-nucleophilic particles.

2) The use of $\alpha$-nucleophilic reagents as the basis of formulations for the cleavage of ecotoxicants makes it possible to provide abnormally high rates of degradation of acyl-containing substrates.

3) The use of nucleophilic oxidation systems hypohalogenic acid / hypohalogenite ion, hydrogen peroxide / hydroperoxide ion allows splitting substrates of various chemical nature with high efficiency.

4) Introduction of an $\alpha$-nucleophilic fragment into the structure of surfactant molecules leads to the creation of supernucleophilic functional detergents, which are one of the most effective reagents in the processes of decomposition of acyl-containing ecotoxicants.

РЕАКЦЙНА ЗДАТНІСТЬ НУКЛЕОФІЛ|В

I ๔-ЕФЕКТ У ПРОЦЕСАХ ЗАМШШЕННЯ

У ЕЛЕКТРОНОДЕФЦЦТНИХ ЦЕНТРІВ

(частина 2)

А. Ф. Попов ${ }^{1}$, I. В. Капітанов ${ }^{1,3}$, Г. О. Сердюк ${ }^{1,3}$, O. Є. Шумейко ${ }^{1,2^{*}}$
${ }^{1}$ Інститут фізико-органічної хімї і вуглехімії імені Л. М. Литвиненка НАН України; вул. Харківське шосе 50, Київ 02160, Україна

${ }^{2}$ Інститут органічної хімї НАН Украӥни; вул. Мурманська 5, Київ 02660, Украӥна

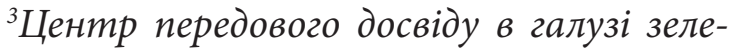
ної хімії Європейського дослідницького простору, відділення хіміі та біотехнологї, факультет наук, Талліннський технічний університет, Академія, 15, Таллінн, 12618, Естонія

*E-mail:ashumeiko@ukr.net

Проведено аналіз даних із реакційної здатності типових неорганічних $\alpha$-нуклеофілів у процесах розщеплення ацилвмісних субстратів, у тому числі ефірів кислот фосфору, які забезпечують аномально високі швидкості реакцій порівняно з іншими супернуклеофілами. Розглянуто різні види таких $а$-нуклеофілів, особливості їхньої структури і реакційної здатності. Показано, що важливою особливістю гідроксиламіну, оксимів і гідроксамових кислот є наявність фрагменту із суміжними атомами О i $\mathrm{N}$ (-N-O-H), що містять одну або більше неподілених пар електронів, що й визначає їхню приналежність до класу $а$-нуклеофілів.

Показано, що за прояв $\alpha$-ефекту і його величину можуть бути відповідальними ціла низка факторів, основними 3 яких $€$ дестабілізація основного стану нуклеофілу внаслідок відштовхування неподілених електронних пар, стабілізація перехідного стану, незвичайна термодинамічна стабільність продуктів реакції, сольватаційні ефекти розчинника, тип гібридизації електрофільного центру та ін.

Особливий інтерес викликає вивчення нуклеофільної реакційної здатності окси- 
мат-іонів, який зумовлений, перш за все, тією обставиною, що саме в ряду цього класу а-нуклеофілів було знайдено ефективні антидоти - реактиватори ацетилхолінестерази. Показано аномально високу реакційну здатність неорганічних $\alpha$-нуклеофілів $\mathrm{HOO}^{-}$i $\mathrm{ClO}^{-}$іонів, які використовують для конструювання рецептур із метою знищення екотоксикантів і бойових отруйних речовин. Важливе значення має використання міцелярних систем для підвищення ефективності реакцій розщеплення екотоксикантів супернуклеофільними реагентами, суть дії яких полягає в зміні локальних концентрацій і реакційної здатності субстратів і реагентів при перенесенні реакції в міцелярну псевдофазу, а також зміщення протолітичних рівноваг у такому розчині. Тут слід зазначити, що найбільш перспективним шляхом підвищення ефективності зв язування нуклеофільних реагентів міцелами $€$ створення функціональних детергентів - ПАР, що містять у своїй структурі реакційноздатні фрагменти. За реалізації такого підходу концентрація нуклеофільних груп на поверхні міцел завжди буде дорівнювати концентрації ПАР.

Наведені нами дані свідчать про перспективність шляху структурної модифікації ПАР, що призводить до створення супернуклеофільних функціоналізованих детергентів, які $є$ одними з найбільш ефективних реагентів у процесах розщеплення ацилвмісних екотоксикантів.

Ключові слова: функціоналізовані ПАР, a-нуклеофіли, міцелярні системи, гідроксиламін, оксими, амідоксими, гідроксамові кислоти, пероксиди.
РЕАКЦИОННАЯ СПОСОБНОСТЬ НУКЛЕОФИЛОВ

И ๙-ЗФФЕКТ В ПРОЦЕССАХ ЗАМЕЩЕНИЯ

У ЭЛЕКТРОНОДЕФИЦИТНЬХ ЦЕНТРОВ (часть 2)

А. Ф. Попов ${ }^{1}$, И. В. Капитанов ${ }^{1,3}$, А. А. Сердюк $\kappa^{1,3}$, А. Е. Шумейко ${ }^{1,2}$ *

${ }^{1}$ Институт фбизико-органической химии и углехимии им. Л.М. Литвиненко НАН Украинь; ул. Харьковское шоссе 50, Киев 02160, Украина

${ }^{2}$ Институт органической химии НАН Украинь; ул. Мурманская 5, Киев 02660, Украина

${ }^{3}$ Центр передового опьта в области зеленой химии Европейского исследовательского пространства, отделение химии и биотехнологии, факультет наук, Таллиннский технический университет, Академия, 15, Таллинн, 12618, Эстония

*e-mail: ashumeiko@ukr.net

В обзоре проанализированы вопросы, связанные с реакционной способностью нуклеофилов и проявлением а-эффекта в процессах замещения у электронодефицитных центров. Обсуждены фундаментальные аспекты этого явления, а также возможности и перспективы использования $\alpha$-нуклеофилов в системах для высокоэффективного расщепления субстратов экотоксикантов различной природы.

Ключевые слова: функционализированные ПАВ, а-нуклеофилы, мицеллярные системы, гидроксиламин, оксимы, амидоксимы, гидроксамовые кислоты, пероксиды. 


\section{ЛИТЕРАТУРА}

94. Ariga K., Kunitake T. Supramolecular chemistry - fundamentals and applications. - Berlin/ Heidelberg, Germany: Springer-Verlag, 2006.

95. Wasserscheid P., Welton T. Ionic Liquids in Synthesis. - Weinheim: Wiley-VCH Verlag $\mathrm{GmbH} \&$ Co. KGaA, 2008.

96. Holmberg K. Handbook of applied surface and colloid chemistry. - Weinheim: WileyVCH Verlag GmbH \& Co. KGaA, 2001.

97. Саввин С., Чернова Р., Штыков С. Поверхностно-активные вещества. - М.: Наука, 1991.

98. Миттела К. Мицеллообразование, солюбилизация, микроэмульсии. - М.: Мир, 1980.

99. Фендлер Е., Фендлер Д. Мицеллярный катализ в органических реакциях // Методы и достижения в физико-органической химии. - М.: Мир, 1973. - С. 222 - 361.

100. Березин И., Мартинек К. Основы физической химии ферментативного катализа. М.: Высшая школа, 1977.

101. Кустов К., Белецкая И. Green Chemistry - новое мышление // Журн. Рос. хим. общ-ва им. Д. И. Менделеева. - 2004. - 48, № 6. - С. 3-12.

102. Арипов Э., Орел М., Аминов С. Гидрофобные взаимодействия в бинарных растворах поверхностно-активных веществ. - Ташкент: Фан, 1980.

103. Pasupati M. The nature of the association equilibria and hydrophobic bonding in aqueous solutions of association colloids // Adv. Coll. Int. Sci. - 1967. - 1, № 3. - P. 242-275.

104. Pasupati M. The hydration of micelles of association colloidal electrolytes // J. Coll. Sci. 1964. - 19, № 8. - P. 722-728.

105. Kamrath R., Frances E. Mass-action model of mixed micellization // J. Phys. Chem. -1984. 88, № 8. - P. 1642-1648.

106. Moroi Y., Sugii R., Matuura R. Examination of micelle formation by phase rule // J. Coll. Int. Sci. - 1984. - 98, № 1. - P. 184-191.
107. Гордон Д. Органическая химия растворов электролитов. - М.: Мир, 1979.

108. Hall B., Carlstrom G. Hydration of ionic surfactant micelles from water oxygen-17 magnetic relaxation // J. Phys. Chem. - 1981. 85, № 14. - P. 2142-2147.

109. Menger F., Doll D. On the structure of micelles // J. Am. Chem. Soc. - 1984. - 106, № 4. - P. 1109-1113.

110. James D., Robinson B., White N. Dynamics of small molecule-micelle interactions: Charge and $\mathrm{pH}$ effects on the kinetics of the interaction of dyes with micelles// J. Coll. Int. Sci. 1977. - 59, № 2. - P. 328-336.

111. Stilbs P. Fourier transform NMR pulsed-gradient spin-echo (FT-PGSE) self-diffusion measurements of solubilization equilibria in SDS solutions // J. Coll. Int. Sci. - 1982. - 87, № 2. P. 385-394.

112. Miyashita Y., Hayano S. Kinetic Study of the Penetration of an Anthraquinoid Acidic Dye into Cationic Micelles // Bull. Chem. Soc. Jap. - 1981. - 54, № 11. - P. 3249-3252.

113. Supernucleophilic systems based on functionalized surfactants in the decomposition of 4-nitrophenyl esters derived from phosphorus and sulfur acids: II. Influence of the length of hydrophobic alkyl substituents on micellar effects of functionalized monomeric and dimeric imidazolium surfactants / I. Kapitanov, I. Belousova, A. Shumeiko, M. Kostrikin, T. Prokop'eva, A. Popov // Russ. J. Org. 2014. - 50, № 5. - P. 693-703.

114. Micellar effects on kinetics and equilibrium of synthesis and hydrolysis of benzylideneaniline: A general kinetic conception of micellar catalysis / K. Martinek, K. Yatsimirski, A. Osipov, I. Berezin // Tetrahedron. - 1973. - 29, № 7. P. 963-969.

115. Яцимирский А. Кинетика и механизм мицеллярного катализа в органических реакциях: дис... канд. хим. н. - М., 1972.

116. Cheong M.-Y. A comparative analysis of 
pseudophase ion-exchange (PIE) model and Berezin pseudophase (BPP) model: Analysis of kinetic data for ionic micellar-mediated semi-ionic bimolecular reaction / M. Cheong, A. Ariffin, M. Khan // Bull. Korean Chem. Soc. - 2007. - 28, № 7. - P. 1135-1140.

117. A NMR study of ion exchange in cationic micelles. Success and failures of models / A. Blasko, C. Bunton, G. Cerichelli, D. McKenzie // J. Phys. Chem. - 1993. - 97, № 43. P. 11324-11332.

118. Physicochemical properties and esterolytic reactivity of oxime functionalized surfactants in $\mathrm{pH}$-responsive mixed micellar system / I. Kapitanov, A. Mirgorodskaya, F. Valeeva, N. Gathergood, K. Kuca, L. Zakharova, Ye. Karpichev // Colloids and Surfaces A: Physicochemical and Engineering Aspects. - 2017. 524. - P. 143-159.

119. Oxime functionality in surfactant self-assembly: An overview on combating toxicity sof organophosphates / N. Singh, Ye. Karpichev, A. Tiwari, K. Kuca, K. Ghosh // Journal of Molecular Liquids. - 2015. - 208. - P. 237-252.

120. Quina F., Chaimovich H. Ion exchange in micellar solution. 1. Conceptual framework for ion exchange in micellar solution // J. Phys. Chem. - 1979. - 83, №. 11. - P. 1844-1850.

121. Menger F., Portnoy C. On the chemistry of reactions proceedings inside molecular aggregates // J. Am. Chem. Soc. - 1967. - 89, № 18. - P. 4698-4707.

122. Al-Lohedan H., Bunton C., Romsted L. Micellar effects upon the reaction of betaine esters with hydroxide ion // J. Phys. Chem. - 1981. 85, № 14. - P. 2123-2129.

123. Al-Lohedan H., Bunton C. Ion binding and micellar effects upon the reaction of carboxylic anhydrides and carbonate esters // J. Org. Chem. - 1982. - 47, №7. - P. 11601166.

124. Raghavan P., Srinivasan V., Venkatasbramanian N. Micellar effects in deacylation of p-nitrophenyl benzoate // Indian J. Chem. 1982. - 21B, № 10. - P. 423-425.

125. A quantitative analysis of the effect of head group bulk on $\mathrm{S}_{\mathrm{N}} 2$ and $\mathrm{E} 2$ reactions in cationic micelles / L. Brinchi, P. Profio, R. Germani, G. Savelli, C. Bunton // Langmuir. - 1997. 13, № 17. - P. 4583-4587.

126. Бегунов А., Рутковский Г. Мицеллярный катализ. II. Влияние природы поверхностно-активных веществ на щелочной гидролиз о-изобутил-о-п-нитрофенилметил-фосфоната // Журн. орган. химии. -1981. - 17, № 9. - C. 1668-1673.

127. Bunton C., Robinson L. Micellar effect upon the reaction of p-nitrophenyl diphenyl phosphate with hydroxide and fluoride ions // J. Org. Chem. - 1969. - 94, № 4. - P. 773-780.

128. Reactivity of co-micellar systems based on dimeric functionalized tetraalkylammonium surfactant in phosphoryl and sulfonyl group transfer processes / T. Prokop'eva, I. Kapitanov, I. Belousova, A. Shumeiko, M. Kostrikin, A. Serdyuk, M. Turovskaya, N. Razumova // Russ. J. Org. Chem. - 2017. - 53, № 4. - P. 510-513.

129. Yatsimirsky A., Martinek K., Berezin I. Mechanism of micellar effects on acylation of aryl oximes by p-nitrophenyl-carboxylates // Tetrahedron. - 1971. - 27. - P. 2855-2859.

130. Reactivity of micellar systems based on supernucleophilic functional surfactants in processes of. acyl group transfer / I. Kapitanov, I. Belousova, M. Turovskaya, E. Karpichev, T. Prokopeva, A. Popov // Russ. J. Org. Chem. - 2012. - 48, № 5. - P. 651-662.

131. Bunton C., Ihara J. Micellar effects upon dephosphorilation and deacylation by oximate ions // J. Org. Chem. - 1977. - 42, № 17. P. 2865-2869.

132. Reactivity of micelle-forming 1-alkyl-3-(1-oximinoethyl) pyridinium halides in acyl group transfers / M. Turovskaya, I. Kapitanov, I. Belousova, K. Tuchinskaya, A. Shumeiko, M. Kostrikin, N. Razumova, T. Prokopeva, A. Popov // 
Theoret. and Experim. Chem. - 2011. - 47, №. 1. - P. 21-29.

133. Umberto T. Catalysis of ester hydrolysis by cationic micelles of surfactants containning the imidazole ring // J. Chem. Soc., Perkin Trans. 2. - 1976, № 6. - P. 771-776.

134. An imidazole-functionalized phosphatidylcholine derivative: nucleophilic vesicles with adjustable reactivity / R. Moss, R. Scrimin, S. Bhattacharya, S. Swarup // J. Am. Chem. Soc. - 1987. - 109, № 20. - P. 6209-6210.

135. Gitler C., Ochoa-Solano A. Carlos G. Nonpolar contributions to the rate of nucleophilic displacements of p-nitrophenyl esters in micelles // J. Am. Chem. Soc. - 1968. - 90, № 18. - P. 5004-5009.

136. Moss R., Nahas R., Ramaswami S. Sequential bifunctional micellar catalysis // J. Am. Chem. Soc. - 1977. - 99, № 2. - P. 627-629.

137. Dephosphorylation in functional micelles. The role of the imidazole group / Brown J., Bunton C., Diaz S., Ihara Y. // J. Org. Chem. - 1980. 45, № 21. - P. 4169-4174.

138. Moss R., Lee Y., Lukas T. Micellar stereoselectivity. Cleavage of diastereomeric substrates by functional surfactant micelles // J. Am. Chem. Soc. - 1979. - 101, № 9. - P. 2499-2501.

139. A comparison of hydroxyl- and imidazole-functionalized micellar catalysts in ester hydrolyses / R. Moss, R. Nahas, S. Ramaswami, W. Sanders // Tetrahedron Lett. - 1975. 16, № 39. - P. 3379-3382.

140. Moss R., Nahas R., Lukas T. A cysteine-functionalized micellar catalyst // Tetrahedron Lett. - 1978. - 19, № 6. - P. 507-510.

141. Bunton C., Ionescu L. Hydrolysis of di- and trisubstituted phosphate esters catalyzed by nucleophilic surfactants // J. Am. Chem. Soc. 1973. - 95, № 9. - P. 2912-2917.

142. Bunton C., McAneny M. Micellar effects on the hydrolysis of $\mathrm{p}$-nitrobenzoyl choline and the related N-hexadecyl ester // J. Org. Chem. - 1976. - 41, № 1. - P. 36-39.
143. Moss R., Ihara Y. Cleavage of phosphate esters by hydroxyl-functionalized micellar and vesicular reagents // J. Org. Chem. - 1983. - 48, № 4. - P. 588-592.

144. Menger F., Whitesell L. A protease mimic with turnover capabilities // J. Am. Chem. Soc. 1985. - 107, № 3. - P. 707-708.

145. Moss R., Bizzigotti G., Huang C. Nucleophilic esterolytic and displacement reactions of a micellar thiocholine surfactant // J. Am. Chem. Soc. - 1980. - 102, № 2. - P. 754-762.

146. Moss R., Hendrickson T., Bizzigotti G. Esterolytic chemistry of vesicular thiocholine surfactant // J. Am. Chem. Soc. - 1986. - 108, № 18. - P. 5520-5527.

147.1-Methyl-3-hexadecyl-2-(oximinomethyl) imidazolium bromide as a new highly efficient, low-basicity reagent for the decomposition of acyl-containing ecotoxicants / A. Popov, I. Kapitanov, M. Orlov, I. Belousova, K. Tuchinskaya, T. Prokop'eva // Theoret. and Experim. Chem. - 2010. - 46, №. 5. P. 309-316.

148. Reiner R., Rossmann K. Nukleophile Substanzen zur Entgiftung von Phosphorestern // Monatshefte für Chemie. - 1982. - 113, № 2. P. 223-231.

149. Пат. DE 2844667A1. Mittel zur Decontamination von mit phosphorhaltigen Giftgasen und Pestiziden verunreinigten Gegenstanden und Korperteilen / R. Reiner, K. Rossmann. Опубл. 1980.

150. Role of the hydrophobic properties of functional detergents on micellar effects in the decomposition of ecotoxicants / I. Belousova, I. Kapitanov, A. Shumeiko, A. Anikeev, M. Turovskaya, T. Zubareva, B. Panchenko, T. Prokopeva, A. Popov // Theoret. and Experim. Chem. - 2010. - 46, № 4. - P. 225-232.

151. Nucleophile ion pairs. 6. Catalytic hydrolysis of p-nitrophenyl acetate by zwitterionic hydroxamate nucleophiles in representative micellar systems / T. Kunitake, Y. Okahata, S. Ta- 
namachi, R. Ando // Bull. Chem. Soc. Jap. 1979. - 52. - P. 1967-1971.

152. Hershfield R., Bender M. Nucleophilic and metal ion acceleration of ester hydrolysis in a hydrophobic complex. A reactive enzyme model system // J. Am. Chem. Soc. -1972. 94, № 4. - P. 1376-1377.

153. Bunton C., Gillitt N., Foroudian H. A quantitative treatment of dephosphorilation by an amphiphilic hydroxamate ion. The role of micellar charge // Langmuir. - 1998. - 14, № 16. - P. 4415-4421.

154. Bunton C. A., Hamed F. H., Romsted L. S. Quantitative treatment of reaction rates in functional micelles and comicelles // J. Phys. Chem. - 1982. - 86, № 11. - P. 2103-2108.

155. Structure of the head group, nucleophilicity, and micellar effects of functional detergents in acyl transfer reactions / I. Belousova, I. Kapitanov, A. Shumeiko, M. Turovskaya, T. Prokopeva , A. Popov // Theoret. and Experim. Chem. - 2008. - 44, № 2. - P. 93-100.

156. Pillersdorf A., Katzhendler J. Dipolar micelles. 8. Hydrolysis of substituted phenyl esters in a hydroxamic acid surfactant // J. Org. Chem. 1979 - 44, № 4. - P. 549-554.

157. Функциональные детергенты, содержащие имидазолиевое ядро и типичные фрагменты $\alpha$-нуклеофилов - основа высокоэффективных мицеллярных систем для расщепления эфиров кислот фосфора / Ю. Симаненко, Е. Карпичев, Т. Прокопьева, А. Латт, А. Попов, В. Савелова, И. Белоусова // Журн. орган. химии. - 2004. - 40, № 2. - C. 234-246.

158. Карпичев Е. Реакционная способность функциональных детергентов на основе $а$-нуклеофилов в процессах переноса ацильной группы: дис... канд. хим. н. - Донецк, 2002.

159. Новые функциональные детергенты на основе имидазола - эффективные реагенты для расщепления эфиров органических кислот / А. Попов, Ю. Симаненко, Т. Прокопьева, Е. Карпичев, А. Матвеев, В. Матвиенко, И. Белоусова, В. Савелова // Теорет. и эксперим. химия. - 2003. - 39, № 1. C. 14-21.

160. Влияние природы головной группы на мицеллярные эффекты сомицелл функциональное/катионное ПАВ в реакциях переноса ацильной группы / И. Белоусова, Е. Карпичев, Т. Прокопьева, Л. Лукьянова, В. Савелова, А. Попов // Теорет. и эксперим. химия. - 2007. - 43, № 1. - С. 30-37.

161. Supernucleophilic systems based on functionalized surfactants in the decomposition of 4-nitrophenyl esters derived from phosphorus and sulfur acids: III. Reactivity of mixed micellar systems based on tetraalkylammonium and imidazolium surfactants / T. Prokop'eva, I. Kapitanov, I. Belousova, A. Shumeiko, M. Kostrikin, M. Turovskaya, N. Razumova, A. Popov // Russ. J. Org. Chem. - 2015. - 51, № 8. - P. 1083-1090.

162. Кислотно-основные свойства функционализированных ПАВ в мицеллярных системах / И. Капитанов, А. Сердюк, А. Шумейко, Т. Прокопьева, А. Попов // Укр. хим. журнал. - 2017. - 83, № 8. - С. 94-102.

163. Nucleophilicity of functional surface active substances in the transfer of phosphoryl groups / M. Turovskaya, T. Prokopeva, E. Karpichev, A. Shumeiko, M. Kostrikin, V. Savelova, I. Kapitanov, A. Popov // Theoret. and Experim. Chem. - 2006. - 42, № 5. P. 295-302.

164. Unusual cource of the p-nitrophenyl phosphate esters cleavage by 3-hydroximinoalkylpyridinium salts in micellar solutions / H. Kotoučová, J. Mazáč, R. Cibulka, F. Hampl, F. Liška / Chem. Lett. - 1998. - 27, № 7. P. 649-650.

165. Amphiphilic quaternary piridinium ketoximes as functional hydrolytic micellar catalysts - does the nucleophilic function position 
influence their reactivity? / H. Kotoučová, R. Cibulka, F. Hampl, F. Liška // J. Mol. Catal. A. - 2001. - 174. - P. 59-62.

166. Quaternary pyridinium ketoximes - new efficient micellar hydrolytic catalysts / R. Cibulka, F. Hampl, H. Kotoučová, J. Mazáč, F. Liška // Collect. Czech. Chem. Comm. - 2000. - 65, № 2. - P. 227-242.

167. Kivala M., Cibulka R., Hampl F. Cleavage of 4-nitrophenyl diphenyl phosphate by isomeric quaternary pyridinium ketoximes - how can structure and lipophilicity of functional surfactants influence their reactivity in micelles and microemulsions? // Collect. Czech. Chem. Comm. - 2006. - 71, № 12. - P. 1642-1658.

168. Мицеллярные эффекты функциональных детергентов - галогенидов 1-цетил-3-(2-оксиминопропил) имидазолия - в реакциях с 4-нитрофенилтолуолсульфонатом и 4-нитрофенилдиэтилфосфатом / А. Попов, Ю. Симаненко, Е. Карпичев, А. Матвеев, В. Матвиенко, Т. Прокопьева // Теорет. и эксперим. химия. - 2001. - 37, № 6. - С. 341-346.

169. Micelles of an oxime-functionalized imidazolium surfactant. Reactivities at phosphorryl and sulfonyl groups / Yu. Simanenko, E. Karpichev, T. Prokop'eva, B. Panchenko, C. Bunton // Langmuir. - 2001. - 17, № 3. P. 581-582.

170. Мицеллярные эффекты функциональных детергентов - галогенидов 1-цетил-3- (2-оксиминопропил) имидазолия - в реакциях с 4-нитрофенилтозилатом, -диэтилфосфатом и -диэтилфосфонатом / Ю. Симаненко, А. Попов, Е. Карпичев, Т. Прокопьева, В. Савелова, К. Бантон // Журн. орган. химии. - 2002. - 38, № 9. - С. 1369-1380.

171. Kapitanov I. Nucleophilicity of micellar systems based on amphiphilic derivatives of 2-(oximinomethyl)-imidazole in the decomposition of 4-nitrophenyl diethyl phosphate // Theoret. and Experim. Chem. - 2011. - 47, № 5. - P. 317-323.
172. Синтез функционализованных оксимными группами ПАВ на основе имидазола, пиридина и алкиламинов / А. Шумейко, М. Кострикин, И. Капитанов, А. Сердюк, Н. Бураков, А. Попов // Укр. хим. журнал. 2019. - 85, № 8. - С. 94-105.

173. Catalysis of the alkaline hydrolysis of 4-nitrophenyl diethyl phosphonate by cationic dimeric surfactant micelles / T. Zubareva, A. Anikeev, E. Karpichev, I. Kapitanov, T. Prokop'eva, A. Popov // Theoret. and Experim. Chem. 2011. - 47, № 2. - P.108-114.

174. Moss R., Kim K., Swarup S. Efficient catalytic cleavage of reactive phosphates by an o-iodosobenzoate functionalized surfactant // J. Am. Chem. Soc. - 1986. - 108, № 4. - P. 788-793.

175. Moss R., Ganguli S. Iodosobenzoate-functionalized surfactant vesicles: adjustable reactivity in reactive phosphate cleavage // Tetrahedron Lett. - 1989. - 30, № 16. - P. 2071-2074.

176. Moss R., Zhang H. Toward a broad spectrum decontaminant for reactive toxic phosphates/ phosphonates: N-alkyl-3-iodosopyridinium4-carboxylates // Tetrahedron Lett. - 1993. 34, № 39. - Р. 6225-6228.

177. Карякин Ю., Ангелов И. Чистые химические вещества. - М.: Химия, 1974.

178. Duynstee E., Grunwald E. Organic Reactions Occurring in or on Micelles. I. Reaction Rate Studies of the Alkaline Fading of Triphenylmethane Dyes and Sulfonphthalein Indicators in the Presence of Detergent Salts // J. Am. Chem. Soc. - 1959. - 81, № 17. - P. 4540-4542.

179. Ginsburg S., Wilson I. Oximes of the Pyridine Series // J. Am. Chem. Soc. - 1957. - 79, № 2. P. 481-485.

180. Acetylcholinesterase reactivators. Pyridyl and anilyl trifluoromethyl ketoximes / R. Salvador, M. Saucier, D. Simon, R. Goyer // J. Med. Chem. - 1972. - 15, № 6. - P. 646-650.

181. Реакции N,N-диалкилкарбоксамидов с галогенами / Н. Бураков, А. Каниболоцкий, Г. Осиченко, В. Михайлов, В. Савело- 
ва, В. Космынин // Журн. орган. химии. 2001. - 37, № 9. - С. 1276-1286.

182. Коростелев П. Приготовление растворов для химико-аналитических работ. - М.: Химия, 1971.

183. Albert A., Sergent E. Ionization Constants of Acids and Bases. - New York: John Wiley \& Sons, 1962.

184. Афифи А., Эйзен С. Статистический анализ. Подход с использованием ЭВМ. М.: Мир, 1982.

185. Yao H., Richardson D. Bicarbonate Surfoxidants: Micellar Oxidations of Aryl Sulfides with Bicarbonate-Activated Hydrogen Peroxide // J. Am. Chem. Soc. - 2003. - 125, № 20. P. 6211-6221.

186. Micellar effects upon dephosphorylation by peroxy anions / C. Bunton, M. Mhala, J. Moffatt, D. Monarres, G. Savelli // J. Org. Chem. 1984. - 49, № 3. - P. 426-430.

187. Bunton C., Foroudian H. A quantitative treatment of micellar effects upon dephosphorylation by the hydroperoxide anion // Langmuir. - 1993. - 9, № 11. - P. 2832-2835.

188. Мицеллярные эффекты катионных детергентов в реакциях расщепления субстратов-экотоксикантов гидроксид-ионом / Ю. Симаненко, А. Попов,Т. Прокопьева, Е. Карпичев, И. Белоусова, В. Савелова В. // Теорет. и эксперим. химия. - 2002. - 38, № 4. - C. 238-244.

189. Нуклеофильная реакционная способность, $\mathrm{HO}^{-}$и $\mathrm{HO}_{2}^{-}$-анионов в водноспиртовых смесях и $\mathrm{HCO}_{4}^{-}$-аниона в воде / В. Савелова, А. Попов, Л. Вахитова, Т. Соломойченко, Ю. Садовский, Т. Прокопьева, А. Скрыпка, Б. Панченко // Журн. орган. химии. - 2005. - 41, № 12. - С. 1810 1818.

190. Катализ гидрокарбонат- и силикат-ионами окисления диэтилсульфида пероксидом водорода в воде и водно-спиртовых смесях / В. Лобачев, В. Савелова, Т. Про- копьева // Теорет. и эксперим. химия. 2004. - 40, № 3. - C. 157-161.

191. Zaugg H. The Bromination of Some N-Substituted Phthalimides with N-Bromosuccinimide // J. Am. Chem. Soc. - 1954. - 76, № 22. - P. 5818-5819.

192. Buckles R. E., Johnson R. C., Probst W. J. Comparison of N-Bromoacetamide and N-Bromosuccinimide as Brominating Agents // J. Org. Chem. - 1957. - 22, № 1. - P. 55-59.

193. Kinetics and mechanism of oxidation of aspirin by bromamine- $\mathrm{T}, \mathrm{N}$-bromosuccinimide, and N-bromophthalimide / R. Ramachandrappa, R. Puttaswamy, S. Mayanna, N. Gowda // Int. J. Chem. Kinet. - 1998. - 30, № 6. P. 407-414.

194. Рыжаков А., Андреев В., Родина Л. Молекулярные комплексы $\mathrm{N}$-оксидов хинолинов и изохинолинов с бромом // Журн. орган. химии. - 1996. - 32, № 6. - С. 128-131.

195. Energy parameters and charge-transfer spectra of the complexes of bromine with substituted pyridines / P. Huyskens, J. D'Hondt, F. Govaerts, Th. Zeegers-Huyskens // J. Phys. Chem. - 1973. - 77, № 13. - P. 1662-1665.

196. Nakagawa T., Andrews L., Keefer R. The Tribromide Equilibrium in Aqueous Acetic Acid // J. Phys. Chem. - 1957. - 61, № 7. P. 1007-1009.

197. Хадсон Р. Реакционная способность и пути реакций. - М.: Мир, 1977.

198. Aubort J., Hudson R., Woodcock R. Enhanced nucleophilic reactivity: The "disappearing" lone-pair // Tetrahedron Lett. - 1973. - 14, № 24. - P. 2229-2232.

199. Органокомплексы тригалогенид-иона а-нуклеофилы и эффективные окислители в реакциях разложения ФОС в воде и мицеллах ПАВ / В. Савелова, К. Бантон, Т. Прокопьева, М. Туровская, Е. Карпичев, В. Михайлов, А. Каниболоцкий, Н. Бураков, А. Попов // Теорет. и эксперим. химия. - 2004. - 40, № 5. - С. 291-297. 
200. Synthesis of cetyltrimethylammonium tribromide (CTMATB) and its application in the selective oxidation of sulfides to sulfoxides / G. Kar, A. Saikia, U. Bora, S. Dehury, M. Chandhuri // Tetrahedron Lett. - 2003. - 44, № 24. P. 4503-4505.

201. Chiappe C., Leandri E., Pieraccini D. Highly efficient bromination of aromatic compounds using 3-methylimidazolium tribromide as reagent/solvent // Chem. Commun. - 2004. № 22. - P. 2536-2537.

202. Mittal K., Fendler E. Solution behavior of surfactant. - New York: Plenum Press, 1980.

203. Toullec J., Moukawim M. Cetyltrimethylammonium hydroperoxide: an efficient reagent for promoting phosphate ester hydrolysis // Chem. Commun. - 1996. № 2. - P. 221-222.

204. Cerichelli G., Mancini G., Luchetti L. Surfactant Control of the Ortho/Para Ratio in the Bromination of Anilines // Tetrahedron. 1994. - 50, № 12. - P. 3797-3802.

205. Jencks W. The Reaction of Hydroxylamine with Activated Acyl Groups. II. Mechanism of the Reaction // J. Am. Chem. Soc. - 1958. - 80, № 17. - Р. 4585-4588.

206. Лобачев В., Рудаков Е. Химия пероксинитрита. Кинетика и механизмы реакций // Успехи химии. - 2006. - 75, № 5. - С. $422-$ 444.

207. Hughes M., Nicklin H. Structure of tetrasulphur dinitride // J. Chem. Soc. A. - 1971. № 1. - P. 164-168.

208. Formation and stability of N-heterocyclic carbenes in water: the carbon acid $\mathrm{p} K_{\mathrm{a}}$ of imidazolium cations in aqueous solution / T. Amyes, S. Diver, J. Richard, F. Rivas, K. Toth // J. Am. Chem. Soc. - 2004. - 126, № 13. - P. 43664374.

209. Alder R., Allen P., Williams S. Stable carbenes as strong bases // J. Chem. Soc. Chem. Commun. - 1995. - № 12. - P. 1267-1268.

210. Симаненко Ю., Попов А., Прокопьева Т. Внутримолекулярный катализ в реакциях гидроксамовых кислот // Теорет. и эксперим. химия. - 2003. - 39, № 5. - С. 280-287.

211. Charge effect in nucleophilic displacement reactions / J. Epstein, P. Cannon, H. Michel, B. Hackley, W. Mosher // J. Am. Chem. Soc. 1967. - 89, № 12. - P. 2937-2943.

\section{REFERENCES}

Numeration of references start in Part 1 of the review (7 Vol 86 No 7 (2020) )

94. Ariga K., Kunitake T. Supramolecular chemistry - fundamentals and applications. (Berlin/ Heidelberg, Germany: Springer-Verlag., 2006).

95. Wasserscheid P., Welton T. Ionic Liquids in Synthesis. (Weinheim: Wiley-VCH Verlag $\mathrm{GmbH} \& \mathrm{Co}$. KGaA, 2008).

96. Holmberg K. Handbook of applied surface and colloid chemistry. (Weinheim: WileyVCH Verlag GmbH \& Co. KGaA, 2001).

97. Savvin S., Chernova R., Shtykov S. Surfactants. (M.: Nauka, 1991). [in Russian].

98. Mittela K. Micelle formation, solubilization, microemulsions. (M.: Mir, 1980). [in Russian].

99. Fendler E., Fendler D. Micellar catalysis in organic reactions // Methods and achievements in physical and organic chemistry. (M.: Mir, 1973). [in Russian].

100. Berezin I., Martinek K. Fundamentals of the physical chemistry of enzymatic catalysis. (M.: Vysshaya Shola, 1977). [in Russian].

101. Kustov K., Beletskaya I. "Green Chemistry" - a new way of thinking. J. Russ. Chem. Society to them D. Mendeleev. 2004.48 (6): 3.

102. Aripov E., Orel M., Aminov S. Hydrophobic interactions in binary solutions of surfactants. (Tashkent: Fan, 1980). [in Russian].

103. Pasupati $\mathrm{M}$. The nature of the association equilibria and hydrophobic bonding in aqueous solutions of association colloids. Adv. Coll. Int. Sci. 1967. 1 (3): 242. 
104. Pasupati M. The hydration of micelles of association colloidal electrolytes. J. Coll. Sci. 1964. 19 (8): 722.

105. Kamrath R., Frances E. Mass-action model of mixed micellization. J. Phys. Chem. 1984. 88 (8): 1642.

106. Moroi Y., Sugii R., Matuura R. Examination of micelle formation by phase rule. J. Coll. Int. Sci. 1984.98 (1): 184.

107. Gordon D. Organic chemistry of electrolyte solutions. (M.: Mir, 1979). [in Russian].

108. Hall B., Carlstrom G. Hydration of ionic surfactant micelles from water oxygen-17 magnetic relaxation. J. Phys. Chem. 1981. 85 (14): 2142.

109. Menger F., Doll D. On the structure of micelles. J. Am. Chem. Soc. 1984.106 (4.): 1109.

110. James D., Robinson B., White N. Dynamics of small molecule-micelle interactions: Charge and $\mathrm{pH}$ effects on the kinetics of the interaction of dyes with micelles. J. Coll. Int. Sci. 1977. 59 (2): 328.

111. Stilbs P. Fourier transform NMR pulsed-gradient spin-echo (FT-PGSE) self-diffusion measurements of solubilization equilibria in SDS solutions. J. Coll. Int. Sci. 1982.87 (2): 385.

112. Miyashita Y., Hayano S. Kinetic Study of the Penetration of an Anthraquinoid Acidic Dye into Cationic Micelles. Bull. Chem. Soc. Jap. 1981. 54 (11): 3249.

113. Kapitanov I., Belousova I., Shumeiko A., Kostrikin M., Prokopeva T., Popov A. Supernucleophilic systems based on functionalized surfactants in the decompositi on of 4-nitrophenyl esters derived from phosphorus and sulfur acids: II. Influence of the length of hydrophobic alkyl substituents on micellar effects of functionalized monomeric and dimeric imidazolium surfactants. Russ. J. Org. Chem. 2014. 50 (5): 693.

114. Martinek K., Yatsimirski A., Osipov A., Berezin I. Micellar effects on kinetics and equilibrium of synthesis and hydrolysis of benzyliden- eaniline: A general kinetic conception of micellar catalysis. Tetrahedron. 1973.29 (7): 963.

115. Yatsimirsky A. Ph. D (Chem) Thesis. (Kyiv, 1972). [in Russian].

116. Cheong M., Ariffin A., Khan M. A comparative analysis of pseudophase ion-exchange (PIE) model and Berezin pseudophase (BPP) model: Analysis of kinetic data for ionic micellarmediated semi-ionic bimolecular reaction. Bull. Korean Chem. Soc. 2007. 28 (7): 1135.

117. Blasko A., Bunton C., Cerichelli G., McKenzie D. A NMR study of ion exchange in cationic micelles. Success and failures of models. J. Phys. Chem. 1993.97 (43): 11324.

118. Kapitanov I., Mirgorodskaya A., Valeeva F., Gathergood N., Kuca K., Zakharova L., Karpichev E. Physicochemical properties and esterolytic reactivity of oxime functionalized surfactants in $\mathrm{pH}$-responsive mixed micellar system. Colloids and Surfaces. A: Physicochemical and Engineering Aspects. 2017. 524: 143.

119. Singh N., Karpichev Ye., Tiwari A., Kuca K., Ghosh K. Oxime functionality in surfactant self-assembly: An overview on combating toxicity of organophosphates. Journal of Molecular Liquids. 2015. 208: 237.

120. Quina F., Chaimovich H. Ion exchange in micellar solution. 1. Conceptual framework for ion exchange in micellar solution. J. Phys. Chem. 1979. 83 (11): 1844.

121. Menger F., Portnoy C. On the chemistry of reactions proceedings inside molecular aggregates. J. Am. Chem. Soc. 1967.89 (18): 4698.

122. Al-Lohedan H., Bunton C., Romsted L. Micellar effects upon the reaction of betaine esters with hydroxide ion. J. Phys. Chem. 1981. 85 (14): 2123.

123. Al-Lohedan H., Bunton C. Ion binding and micellar effects upon the reaction of carboxylic anhydrides and carbonate esters. J. Org. Chem. 1982. 47 (7): 1160.

124. Raghavan P., Srinivasan V., Venkatasbramanian N. Micellar effects in deacylation of 
p-nitrophenyl benzoate. Indian J. Chem. 1982. 21B (10): 423.

125. Brinchi L., Profio P., Germani R., Savelli G., Bunton C. A quantitative analysis of the effect of head group bulk on $\mathrm{S}_{\mathrm{N}} 2$ and $\mathrm{E} 2$ reactions in cationic micelles. Langmuir. 1997. 13 (17): 4583.

126. Begunov A., Rutkovsky G. Micellar catalysis. II. The effect of the nature of surfactants on the alkaline hydrolysis of o-isobutyl-o-p-nitrophenylmethylphosphonate. Russ. J. Org. Chem. 1981. 17 (9): 1668.

127. Bunton C., Robinson L. Micellar effect upon the reaction of p-nitrophenyl diphenyl phosphate with hydroxide and fluoride ions. J. Org. Chem. 1969. 94 (4): 773.

128. Prokop'eva T., Kapitanov I., Belousova I., Shumeiko A., Kostrikin M., Serdyuk A., Turovskaya M., Razumova N. Reactivity of co-micellar systems based on dimeric functionalized tetraalkylammonium surfactant in phosphoryl and sulfonyl group transfer processes. Russ. J. Org. Chem. 2017. 53 (4): 510.

129. Yatsimirsky A., Martinek K., Berezin I. Mechanism of micellar effects on acylation of aryl oximes by p-nitrophenyl-carboxylates. Tetrahedron. 1971. 27: 2855.

130. Kapitanov I., Belousova I., Turovskaya M., Karpichev E., Prokopeva T., Popov A. Reactivity of micellar systems based on supernucleophilic functional surfactants in processes of. acyl group transfer. Russ. J. Org. Chem. 2012. 48 (5): 651.

131. Bunton C., Ihara J. Micellar effects upon dephosphorilation and deacylation by oximate ions. J. Org. Chem. 1977. 42 (17): 2865.

132. Reactivity of micelle-forming 1-alkyl-3-(1-oximinoethyl) pyridinium halides in acyl group transfers / Turovskaya M., Kapitanov I., Belousova I., Tuchinskaya K., Shumeiko A., Kostrikin M., Razumova N., Prokop'eva T., Popov A. // Theoret. and Ex-perim. Chem. 2011. 47 (1): 21 .
133. Umberto T. Catalysis of ester hydrolysis by cationic micelles of surfactants containning the imidazole ring. J. Chem. Soc., Perkin Trans. 2. 1976. (6): 771.

134. Moss R., Scrimin P., Bhattacharya S., Swarup S. An imidazole-functionalized phosphatidylcholine derivative: nucleophilic vesicles with adjustable reactivity. J. Am. Chem. Soc. 1987. 109 (20): 6209.

135. Gitler C., Ochoa-Solano A. Carlos G. Nonpolar contributions to the rate of nucleophilic displacements of p-nitrophenyl esters in micelles. J. Am. Chem. Soc. 1968. 90 (18): 5004.

136. Moss R., Nahas R., Ramaswami S. Sequential bifunctional micellar catalysis. J. Am. Chem. Soc. 1977.99 (2): 627.

137. Brown J., Bunton C., Diaz S., Ihara Y. Dephosphorylation in functional micelles. The role of the imidazole group. J. Org. Chem. 1980. 45 (21): 4169.

138. Moss R., Lee Y., Lukas T. Micellar stereoselectivity. Cleavage of diastereomeric substrates by functional surfactant micelles. J. Am. Chem. Soc. 1979. 101 (9): 2499.

139. Moss R., Nahas R., Ramaswami S., Sanders W. A comparison of hydroxyl- and imidazolefunctionalized micellar catalysts in ester hydrolyses. Tetrahedron Lett. 1975.16 (39): 3379.

140. Moss R., Nahas R., Lukas T. A cysteine-functionalized micellar catalyst. Tetrahedron Lett. 1978. 19 (6): 507.

141. Bunton C., Ionescu L. Hydrolysis of di- and trisubstituted phosphate esters catalyzed by nucleophilic surfactants. J. Am. Chem. Soc. 1973.95 (9): 2912.

142. Bunton C., McAneny M. Micellar effects on the hydrolysis of p-nitrobenzoyl choline and the related N-hexadecyl ester. J. Org. Chem. 1976. 41 (1): 36.

143. Moss R., Ihara Y. Cleavage of phosphate esters by hydroxyl-functionalized micellar and vesicular reagents. J. Org. Chem. 1983. 48 (4): 588.

144. Menger F., Whitesell L. A protease mimic with 
turnover capabilities. J. Am. Chem. Soc. 1985. 107 (3): 707.

145. Moss R., Bizzigotti G., Huang C. Nucleophilic esterolytic and displacement reactions of a micellar thiocholine surfactant. J. Am. Chem. Soc. 1980. 102 (2):.754.

146. Moss R., Hendrickson T., Bizzigotti G. Esterolytic chemistry of vesicular thiocholine surfactant. J. Am. Chem. Soc. 1986. 108 (18): 5520.

147. Popov A., Kapitanov I., Orlov M., Belousova I., Tuchinskaya K., Prokop'eva T. 1-Methyl-3-hexadecyl-2-(oximinomethyl) imidazolium bromide as a new highly efficient, low-basicity reagent for the decomposition of acyl-containing ecotoxicants. Theoret. and Experim. Chem. 2010. 46 (5): 309.

148. Reiner R., Rossmann K. Nukleophile Substanzen zur Entgiftung von Phosphorestern. Monatshefte für Chemie. 1982. 113 (2): 223.

149. Пат. DE 2844667A1. Reiner R., Rossmann K. Mittel zur Decontamination von mit phosphorhaltigen Giftgasen und Pestiziden verunreinigten Gegenstanden und Korperteilen. 1980.

150. Belousova I., Kapitanov I., Shumeiko A., Anikeev A. Turovskaya M., Zubareva T., Panchenko B., Prokopeva T., Popov A. Role of the hydrophobic properties of functional detergents on micellar effects in the decomposition of ecotoxicants. Theoret. and Experim. Chem. 2010. 46 (4): 225.

151. Kunitake T., Okahata Y., Tanamachi S., Ando R. Nucleophile ion pairs. 6. Catalytic hydrolysis of p-nitrophenyl acetate by zwitterionic hydroxamate nucleophiles in representative micellar systems. Bull. Chem. Soc. Jap. 1979. 52: 1967.

152. Hershfield R., Bender M. Nucleophilic and metal ion acceleration of ester hydrolysis in a hydrophobic complex. A reactive enzyme model system. J. Am. Chem. Soc. 1972.94 (4): 1376.

153. Bunton C., Gillitt N., Foroudian H. A quan- titative treatment of dephosphorilation by an amphiphilic hydroxamate ion. The role of micellar charge. Langmuir. 1998. 14 (16): 4415.

154. Bunton C.A., Hamed F.H., Romsted L.S. Quantitative treatment of reaction rates in functional micelles and comicelles. J. Phys. Chem. 1982. 86 (11): 2103.

155. Belousova I., Kapitanov I., Shumeiko A., Turovskaya M., Prokopeva T., Popov A. Structure of the head group, nucleophilicity, and micellar effects of functional detergents in acyl transfer reactions. Theoret. and Experim. Chem. 2008. 44 (2): 93.

156. Pillersdorf A., Katzhendler J. Dipolar micelles. 8. Hydrolysis of substituted phenyl esters in a hydroxamic acid surfactant. J. Org. Chem. 1979. 44 (4): 549.

157. Simanenko Yu., Karpichev E., Prokopyeva T., Latt A., Popov A., Savelova V., Belousova I. Functional detergents containing imidazolium core and typical fragments of $\alpha$-nucleophiles the basis of highly efficient micellar systems for the splitting of esters of phosphorus acids. Russ. J. Org. Chem. 2004. 40 (2): 234.

158. Karpichev E. Ph. D (Chem.) Thesis. (Donetsk, 2002). [in Russian].

159. Popov A., Simanenko Yu., Prokopieva T., Karpichev E., Matveev A., Matvienko V., Belousova I., Savelova V. New functional detergents based on imidazole - effective reagents for the breakdown of esters of organic acids. Theoret. and Experim. Chem. 2003.39 (1): 14.

160. Belousova I., Karpichev E., Prokopyeva T., Lukyanova L., Savelova V., Popov A. The influence of the nature of the head group on the micellar effects of functional cationic surfactants in the reactions of acyl transfer. Theoret. and Experim. Chem. 2007. 43 (1): 30.

161. Prokop'eva T., Kapitanov I., Belousova I., Shumeiko A., Kostrikin M., Turovskaya M., Razumova N., Popov A. Supernucleophilic systems based on functionalized surfactants in the decomposition of 4-nitrophenyl esters 
derived from phosphorus and sulfur acids: III. Reactivity of mixed micellar systems based on tetraalkylammonium and imidazolium surfactants. Russ. J. Org. Chem. 2015. 51 (8):1083.

162. Kapitanov I., Serdyuk A., Shumeiko A., Prokop'eva T., Popov A. Acid-base properties of functionalized surfactants in micellar systems. Ukr. J. Chem. 2017. 83 (8): 94.

163. Turovskaya M., Prokop'eva T., Karpichev E., Shumeiko A., Kostrikin M., Savelova V., Kapitanov I., Popov A. Nucleophilicity of functional surface active substances in the transfer of phosphoryl groups. Theoret. and Experim. Chem. 2006. 42 (5): 295.

164. Kotoučová H., Mazáč J., Cibulka R., Hampl F., Liška F. Unusual cource of the p-nitrophenyl phosphate esters cleavage by 3-hydroximinoalkylpyridinium salts in micellar solutions. Chem. Lett. 1998. 27 (7): 649.

165. Kotoučová H., Cibulka R., Hampl F., Liška F. Amphiphilic quaternary piridinium ketoximes as functional hydrolytic micellar catalysts - does the nucleophilic function position influence their reactivity? J. Mol. Catal. A. 2001. 174: 59.

166. Cibulka R., Hampl F., Kotoučová H., Mazáč J., Liška F. Quaternary pyridinium ketoximes new efficient micellar hydrolytic catalysts. Collect. Czech. Chem. Comm. 2000.65 (2): 227.

167. Kivala M., Cibulka R., Hampl F. Cleavage of 4-nitrophenyl diphenyl phosphate by isomeric quaternary pyridinium ketoximes - how can structure and lipophilicity of functional surfactants influence their reactivity in micelles and microemulsions? Collect. Czech. Chem. Comm. 2006. 71, (12): 1642.

168. Popov A., Simanenko Yu., Karpichev E., Matveev A., Matvienko V., Prokopyeva T. Micellar effects of functional detergents - 1-cetyl-3(2-hydroxyminopropyl)- imidazolium halides in reactions with 4-nitrophenyltoluenesulfonate and 4-nitrophenyl diethylphosphate. Theoret. and Experim. Chem. 2001.37 (6): 341.
169. Simanenko Yu., Karpichev E., Prokop'eva T., Panchenko B., Bunton C. Micelles of an oxime-functionalized imidazolium surfactant. Reactivities at phosphorryl and sulfonyl groups. Langmuir. 2001. 17 (3): 581.

170. Simanenko Yu., Popov A., Karpichev E., Prokopyeva T., Savelova V., Bunton K. Micellar effects of functional detergents - 1-cetyl-3(2-hydroxyminopropyl)- imidazolium halides in reactions with 4-nitrophenyltosylate, diethylphosphate and diethylphosphonate. Russ. J. Org. Chem. 2002.38 (9): 1369.

171. Kapitanov I. Nucleophilicity of micellar systems based on amphiphilic derivatives of 2-(oximinomethyl)-imidazole in the decomposition of 4-nitrophenyl diethyl phosphate. Theoret. and Experim. Chem. 2011.47 (5): 317.

172. Shumeiko A., Kostrikin M., Kapitanov I., Serdyuk A., Burakov N., Popov A. Synthesis of functionalized surfactants on the basis of imidazole, pyridine and alkylamines. Ukr. J. Chem. 2019. 85 (8): 94.

173. Zubareva T., Anikeev A., Karpichev E., Kapitanov I., Proko p'eva T., Popov A. Catalysis of the alkaline hydrolysis of 4-nitrophenyl diethyl phosphonate by cationic dimeric surfactant micelles. Theoret. and Experim. Chem. 2011.47 (2): 108.

174. Moss R., Kim K., Swarup S. Efficient catalytic cleavage of reactive phosphates by an o-iodosobenzoate functionalized surfactant. J. Am. Chem. Soc. 1986.108 (4): 788.

175. Moss R., Ganguli S. Iodosobenzoate-functionalized surfactant vesicles: adjustable reactivity in reactive phosphate cleavage. Tetrahedron Lett. 1989. 30 (16): 2071.

176. Moss R., Zhang H. Toward a broad spectrum decontaminant for reactive toxic phosphates/phosphonates: N-alkyl-3-iodosopyridinium-4-carboxylates. Tetrahedron Lett. 1993. 34 (39): 6225.

177. Karyakin Yu., Angelov I. Pure chemicals. (M.: Khimiya, 1974). [in Russian]. 
178. Duynstee E., Grunwald E. Organic Reactions Occurring in or on Micelles. I. Reaction Rate Studies of the Alkaline Fading of Triphenylmethane Dyes and Sulfonphthalein Indicators in the Presence of Detergent Salts. J. Am. Chem. Soc. 1959. 81 (17): 4540.

179. Ginsburg S., Wilson I. Oximes of the Pyridine Series. J. Am. Chem. Soc. 1957. 79 (2): 481.

180. Salvador R., Saucier M., Simon D., Goyer R. Acetylcholinesterase reactivators. Pyridyl and anilyl trifluoromethyl ketoximes. J. Med. Chem. 1972. 15 (6): 646.

181. Burakov N., Kanibolotsky A., Osichenko G., Mikhailov V., Savelova V., Kosmynin V. Reactions of N, N-dialkylcarboxamides with halogens. Russ. J. Org. Chem. 2001.37 (9): 1276.

182. Korostelev P.. Preparation of solutions for chemical analytical work. (M.: Khimiya, 1971). [in Russian].

183. Albert A., Sergent E. Ionization Constants of Acids and Bases. (New York: John Wiley \& Sons,, 1962).

184. Afifi A., Eisen S. Statistical analysis. The approach using computers. (М.: Мир, 1982).

185. Yao H., Richardson D. Bicarbonate Surfoxidants: Micellar Oxidations of Aryl Sulfides with Bicarbonate-Activated Hydrogen Peroxide. J. Am. Chem. Soc. 2003. 125 (20): 6211.

186. Bunton C., Mhala M., Moffatt J., Monarres D., Savelli G. Micellar effects upon dephosphorylation by peroxy anions. J. Org. Chem. 1984. 49 (3): 426.

187. Bunton C., Foroudian H. A quantitative treatment of micellar effects upon dephosphorylation by the hydroperoxide anion. Langmuir. 1993.9 (11): 2832.

188. Simanenko Yu., Popov A., Prokopyeva T, Karpichev E., Belousova I., Savelova V. The micellar effects of cationic detergents in the reactions of the splitting of ecotoxicant substrates with hydroxide-ion. Theoret. and Experim. Chem. 2002. 38 (4): 238.

189. Savelova V., Popov A., Vakhitova L., Solomoy- chenko T., Sadovsky Y., Prokopyeva T., Skrypka A., Panchenko B. The nucleophilic reactivity of $\mathrm{HO}^{-}$and $\mathrm{HO}_{2}{ }^{-}$anions in water-alcohol mixtures and $\mathrm{HCO}_{4}{ }^{-}$anions in water. Russ. J. Org. Chem. 2005.41 (12): 1810.

190. Lobachev V., Savelova V., Prokopyeva T. Catalysis by bicarbonate and silicate ions of the oxidation of diethyl sulfide with hydrogen peroxide in water and water-alcohol mixtures. Theoret. and Experim. Chem. 2004.40 (3): 157.

191. Zaugg H. The Bromination of Some N-Substituted Phthalimides with N-Bromosuccinimide. J. Am. Chem. Soc. 1954. 76 (22): 5818.

192. Buckles R.E., Johnson R.C., Probst W.J. Comparison of N-Bromoacetamide and N-Bromosuccinimide as Brominating Agents. J. Org. Chem. 1957. 22 (1): 55.

193. Ramachandrappa R., Puttaswamy R., Mayanna S., Gowda N. Kinetics and mechanism of oxidation of aspirin by bromamine- $\mathrm{T}$, N-bromosuccinimide, and N-bromophthalimide. Int. J. Chem. Kinet. 1998. 30 (6): 407.

194. Ryzhakov A., Andreev V., Rodina L. Molecular complexes of $\mathrm{N}$-oxides of quinolines and isoquinolines with bromine. Russ. J. Org. Chem. 1996. 32 (6): 128.

195. Huyskens P., D’Hondt J., Govaerts F., Zeegers-Huyskens Th. Energy parameters and charge-transfer spectra of the complexes of bromine with substituted pyridines. J. Phys. Chem. 1973. 77 (13): 1662.

196. Nakagawa T., Andrews L., Keefer R. The Tribromide Equilibrium in Aqueous Acetic Acid. J. Phys. Chem. 1957.61 (7): 1007.

197. Hudson R. Reactivity and reaction pathways. (M.: Mir, 1977). [in Russian].

198. Aubort J., Hudson R., Woodcock R. Enhanced nucleophilic reactivity: The "disappearing" lone-pair. Tetrahedron Lett. 1973. 14 (24): 2229.

199. Savelova V., Banton K., Prokopyeva T., Turovskaya M., Karpichev E., Mikhailov V., 
Kanibolotsky A., Burakov N., Popov A. Organo-complexes of the trihalide ion - $\alpha$-nucleophiles and effective oxidizing agents in the decomposition of FOS in water and surfactant micelles. Theoret. and Experim. Chem. 2004. 40 (5): 291.

200. Kar G., Saikia A., Bora U., Dehury S., Chandhuri M. Synthesis of cetyltrimethylammonium tribromide (CTMATB) and its application in the selective oxidation of sulfides to sulfoxides. Tetrahedron Lett. 2003. 44 (24): 4503.

201. Chiappe C., Leandri E., Pieraccini D. Highly efficient bromination of aromatic compounds using 3-methylimidazolium tribromide as reagent/solvent. Chem. Commun. 2004. (22): 2536.

202. Mittal K., Fendler E. Solution behavior of surfactant. (New York: Plenum Press, 1980).

203. Toullec J., Moukawim M. Cetyltrimethylammonium hydroperoxide: an efficient reagent for promoting phosphate ester hydrolysis. Chem. Commun. 1996. (2): 221.

204. Cerichelli G., Mancini G., Luchetti L. Surfactant Control of the Ortho/Para Ratio in the Bromination of Anilines. Tetrahedron. 1994. 50 (12): 3797.
205. Jencks W. The Reaction of Hydroxylamine with Activated Acyl Groups. II. Mechanism of the Reaction. J. Am. Chem. Soc. 1958. 80 (17): 4585.

206. Lobachev V., Rudakov E. Chemistry of peroxynitrite. Kinetics and reaction mechanisms. Uspekhi Khimii. 2006. 75 (5): 422.

207. Hughes M., Nicklin H. Structure of tetrasulphur dinitride. J. Chem. Soc. A. 1971. (1): 164.

208. Amyes T., Diver S., Richard J., Rivas F., Toth K. Formation and stability of N-heterocyclic carbenes in water: the carbon acid $\mathrm{p} K_{\mathrm{a}}$ of imidazolium cations in aqueous solution. J. Am. Chem. Soc. 2004.126 (13): 4366.

209. Alder R., Allen P., Williams S. Stable carbenes as strong bases. J. Chem. Soc. Chem. Commun. 1995. (12): 1267.

210. Simanenko Yu., Popov A., Prokopyeva T. Intramolecular catalysis in the reactions of hydroxamic acids. Theoret. and Experim. Chem. 2003. 39 (5): 280.

211. Epstein J., Cannon P., Michel H., Hackley B., Mosher W. Charge effect in nucleophilic displacement reactions. J. Am. Chem. Soc. 1967. 89 (12): 2937.

Статья направлена в редакцию «24» марта 2020 года. 